\title{
PENGARUH UKURAN PERUSAHAAN DAN LEVERAGE TERHADAP NILAI PERUSAHAAN (STUDI PADA PERUSAHAAN INDUSTRI TEKSTIL DAN GARMEN YANG TERDAFTAR DI BURSA EFEK INDONESIA TAHUN 2018-2020)
}

\author{
Mislinawati $^{\mathbf{a}^{*}}$, Annisa Fahira ${ }^{\mathbf{b}^{*}}$, Cut Faradilla ${ }^{\mathrm{c}^{*}}$ Cut Yunina Eriva ${ }^{\mathrm{d}}$ \\ a,b,c,d Politeknik Aceh, - Banda Aceh \\ Email: Mislina@politeknikaceh.ac.id ${ }^{d^{*}}$
}

\begin{abstract}
ABSTRAK
Penelitian ini bertujuan untuk mengetahui pengaruh ukuran perusahaan dan leverage terhadap nilai perusahaan pada perusahaan Industri Tekstil dan Garmen yang terdapat di Bursa Efek Indonesia pada tahun 2018-2020. Data yang digunakan adalah laporan keuangan tahunan 2018-2020 pada perusahaan industri tekstil dan garmen. Berdasarkan kriteria penentuan sampel didapatkan 15 perusahaan yang akan diamati pada penelitian ini. Analisis data dilakukan dengan menggunakan metode regresi linier berganda dengan bantuan program SPSS versi 24. Hasil penelitian menunjukkan bahwa ukuran perusahaan berpengaruh negatif signifikan terhadap nilai perusahaan sedangkan leverage berpengaruh positif signifikan terhadap nilai perusahaan.

Kata Kunci : Ukuran Perusahaan, Leverage, dan Nilai Perusahaan.
\end{abstract}

\begin{abstract}
This study aims to determine the effect of firm size and leverage on firm value in Textile and Garment Industry companies listed on the Indonesia Stock Exchange in 20182020. The data used were 2018-2020 annual financial report for textile and garment industry companies. Based on the criteria obtained 15 companies that will be observed in this study. Data analysis was performed using multiple linear regression method with the help SPSS version 24 program. The results showed that firm size had a negative and significant effect on stock prices, while leverage had a positive and significant effect on firm value of.

Keywords: Firm Size, Leverage, and Firm value.
\end{abstract}

\section{PENDAHULUAN}

Setiap perusahaan akan berusaha untuk memaksimalkan nilai perusahaannya karena peningkatan nilai perusahaan merupakan sebuah prestasi yang sesuai dengan tujuan perusahaan go-public. Dalam hal mewujudkan tujuan tersebut perusahaan harus memenuhi kebutuhan dana agar dapat mengoptimalkan kinerjanya. Kinerja yang optimal dapat membantu meningkatkan harga saham serta nilai perusahaan.

Salah satu subsektor Industri yang nilai perusahaannya membukukan kinerja buruk dalam beberapa tahun ini adalah industri Tekstil dan Garmen. Berdasarkan data dari harian CNBC Indonesia pada tanggal 3 Oktober 2019, Indeks sektor aneka industri tekstil dan garmen ini mencatat kinerja hasil terburuk sepanjang sembilan bulan pertama tahun 2019 dengan melemah 16,05\%. Dari 19 saham emiten tekstil dan garmen yang terdaftar di Bursa Efek Indonesia (BEI) pada periode 2 Januari hingga 30 september 2019, terdapat sembilan saham yang menorehkan imbal hasil negatif, bahkan anjlok hingga lebih dari 50\%. Data 
pergerakan harga pasar menunjukkan saham PT Asia Pacific Fibers Tbk (POLY) menurun 54,42\%, PT Indo-Rama Synthetics Tbk (INDR) melemah 38,97\%, PT Tifico Fiber Indonesia Tbk(TFCO) turun 36,54\%, PT Asia Pacific Investama Tbk (MYTX) melemah 35,58\%, dan PT Nusantara Inti Corpara Tbk (UNIT) turun sebanyak 25,58\%. (www.cnbcindonesia.com)

Berdasarkan data dari Bursa Efek Indonesia, rata-rata harga saham perusahaan subsektor tekstil dan garmen mengalami penurunan hampir mencapai 40\% dari tahun 2018 dibandingkan dengan tahun 2019 dan 2020. Rata-rata harga saham industri tekstil dan garmen tahun 2020 sebesar Rp.668, tahun 2019 menurun 38\% sebesar Rp. 416, sedangkan tahun 2020 sebesar RP.430 atau menurun 36\% jika dibandingkan dengan tahun 2018 . Saham-saham industri tekstil dan garmen terpapar aksi jual oleh pelaku pasar didorong oleh menurunnya kinerja fundamental perusahaan karena dilanda arus impor di sektor produk hulu dan meningkatnya persaingan untuk pasar ekspor, dimana hal ini berujung pada pemberhentian karyawan masal dan penutupan pabrik (cnbcindonesia.com).

Penurunan harga saham tersebut juga terjadi karena volume produksi dan ekspor tekstil yang anjlok. Seperti yang dikatakan oleh perencana bidang Perdagangan Badan Perencanaan dan Pembangunan Nasional (Bappenas) pada harian Kontan yang diterbitkan 26 Maret 2021, bahwa secara signifikan permintaan global untuk produk pakaian menurun dan produksi serta rantai nilai global terganggu. Pada Mei 2020 misalnya, ekspor tekstil dan produksi tekstil Indonesia turun drastis sebesar 52\% dibandingkan dengan bulan yang sama 2019. Ini melanjutkan tren yang memburuk sejak Maret dan April 2020. Dikutip dari (Katadata.co.id, 2020) Permintaan pakaian di masa pandemi pun terus menurun seiring tutupnya mall dan pusat perbelanjaan. Pengurangan karyawan juga dilakukan karena utilitas produksi tekstil menyusut hingga 90\%, sedangkan volume produksi turun hingga $85 \%$.

Tidak hanya mengalami penururunan harga saham, kas pada perusahaan industri tekstil dan garmen juga menurun. Dilansir dari harian online Katadata pada April 2020, ratarata pengusaha tekstil kehabisan kas pada juni 2020 dikarenakan pembayaran dari ekspor dan dalam negeri tidak mengalir. Penurunan angka kas perusahaan ini akan berdampak pada penurunan nilai aset perusahaan yang berperan sebagai tolak ukur ukuran perusahaan. Turunnya nilai perusahaan ini juga masih berlanjut hingga tahun 2020 dikarenakan krisis yang melanda Industri Tekstil Indonesia. Di saat permintaan global yang melemah, perusahaan tekstil domestik dihadapkan pada permasalahan utang jatuh tempo yang tidak dapat dibayar hingga menyelesaikan permasalahan utang dengan cara Penundaan Kewajiban Pembayaran Utang (PKPU) di pengadilan niaga. Salah satu perusahaan yang menghadapi PKPU adalah PT Indah Jaya Textile Industry yang merupakan produsen handuk ternama dengan merek Terry Palmer. Gugatan ini diajukan PT Tunas Ruang Mesin di Pengadilan Negeri Jakarta Pusat pada 27 Januari 2021 dengan nomor perkara 57/Pdt.SusPKPU/2021/PN Niaga Jakarta Pusat. Selain perusahaan tersebut terdapat pula peristiwa krisis utang yang membelit Duniatex Group yang menyita perhatian publik dikarenakan perusahaan Duniatex Group tersebut termasuk produsen tekstil terbesar di Indonesia (www.kontan.co.id).

Oleh karena banyaknya perusahaan industri tekstil dan garmen memiliki kendala dalam pengelolaan utang perusahaan, penulis ingin meneliti lebih lanjut mengenai pengaruh rasio utang (leverage) dimana rasio ini melihat bagaimana kemampuan perusahaan dalam 
mengelola perusahaan terhadap nilai perusahaan. Menurut (Sjahrial, 2009), leverage adalah penggunaan aktiva dan sumber dana oleh perusahaan yang memiliki biaya tetap (beban tetap) berarti sumber dana yang berasal dari pinjaman karena memiliki bunga sebagai beban tetap dengan maksud agar meningkatkan keuntungan potensial pemegang saham.

Ada beberapa penelitian mengenai pengaruh ukuran perusahaan terhadap nilai perusahaan. Ukuran perusahaan merupakan cerminan dari total aset perusahaan (Rahayu \& Sari, 2018). Berdasarkan penelitian terdahulu terdapat hasil yang berbeda mengenai pengaruh ukuran perusahaan terhadap nilai perusahaan. Penelitian yang dilakukan oleh Firdaus (2018), Bernandhi (2014), dan Prasetyorini (2013) mengatakan bahwa ukuran perusahaan berpengaruh terhadap nilai perusahaan. Namun penelitian tersebut berbanding terbalik dengan penelitian yang dilakukan oleh Astriani (2014) dan Sholekah \& Venusita (2014) yang menyatakan bahwa ukuran perusahaan tidak berpengaruh terhadap nilai perusahaan.

Selain ukuran perusahaan, penelitian lain yang dilakukan adalah Pengaruh Leverage terhadap nilai perusahaan. Leverage merupakan alat untuk mengukur seberapa besar perusahaan dibiayai dengan utang. Hal ini dapat dilihat dari berbagai penelitian seperti yang dilakukan oleh Rudangga \& Sudiarta (2016), Bernandhi (2014), dan Farooq (2016) menyatakan bahwa secara signifikan leverage berpengaruh terhadap nilai perusahaan, namun berbanding terbalik dengan penelitian yang dilakukan oleh Al-Shehat (2020) dan Astriani (2014) yang menyatakan bahwa leverage tidak berpengaruh terhadap nilai perusahaan. Oleh karena latar belakang permasalahan yang telah dijelaskan diatas, dan juga keberagaman hasil dari penelitian terdahulu maka penelitian ini akan mengangkat judul "Pengaruh Ukuran Perusahaan dan Leverage terhadap Nilai Perusahaan Industri Manufaktur Tekstil dan Garmen Tahun 2018-2020".

\section{KERANGKA TEORITIS DAN PENGEMBANGAN HIPOTESIS Nilai Perusahaan}

Menurut Hery (2015:2) nilai perusahaan merupakan perpepsi investor terhadap tingkat keberhasilan perusahaan yang sering dikaitkan dengan harga saham. Menurut Rahayu \& Sari (2018) nilai perusahan adalah suatu kondisi yang telah diraih oleh suatu perusahaan yang tercermin dalam harga pasar saham perusahaan tersebut. Harmono (2014:233) menyebutkan bahwa nilai perusahaan adalah kinerja perusahaan yang dicerminkan oleh harga saham yang dibentuk oleh permintaan dan penawaran di pasar modal yang merefleksikan penilaian masyarakat terhadap kinerja perusahaan. Berdasarkan pengertian diatas maka dapat disimpulkan bahwa nilai perusahaan adalah penilaian terhadap keberhasilan perusahaan yang dapat dilihat melalui harga saham perusahan.

\section{Harga saham}

Menurut Sartono (2010:70) harga saham terbentuk melalui mekanisme permintaan dan penawaran di pasar modal. Apabila suatu saham mengalami kelebihan permintaan maka harga saham cenderung naik. Sebaliknya, apabila kelebihan penawaran maka harga saham cenderung turun. 
Menurut Brigham dan Houston (2010:7) Harga saham adalah harga yang menentukan kekayaan pemegang saham. Menurut Jogianto (2013:167) harga saham adalah harga suatu saham yang terjadi di pasar bursa pada saat tertentu yang ditentukan oleh pelaku pasar dan ditentukan oleh permintaan dan penawaran saham yang bersangkutan di pasar modal. Berdasarkan pengertian para ahli diatas maka dapat disimpulkan pengertian harga saham adalah harga yang terbentuk dari permintaan dan penawaran di pasar saham.

\section{Pengukuran Nilai Perusahaan}

Salah satu alternatif indikator yang dapat digunakan untuk mencari nilai perusahaan adalah Tobin's Q. Tobin's q adalah indikator untuk mengukur kinerja perusahaan, khususnya tentang nilai perusahaan, yang menunjukkan suatu performa manajemen dalam mengelola aktiva perusahaan. Rasio ini dikembangkan oleh profesor James Tobin pada tahun 1968 (Weston dan Copelan, 2008:245).

Dalam penggunaannya, Tobin'Q mengalami modifikasi. Modifikasi Tobin's Q versi Chung dan Pruitt (1994) telah digunakan secara konsisten karena telah sederhanakan di berbagai simulasi permainan. Pengukuran Tobin's Q untuk perusahaan non keuangan adalah sebagai berikut :

$$
\text { Tobin's } Q=\frac{\text { MVE }+ \text { Debt }}{\text { total assets }}
$$

Keterangan :

Market Value of Equity $(M V E)=$ Nilai pasar dari saham beredar (Harga saham penutupan akhir tahun x jumlah saham beredar)

Debt = Nilai total kewajiban perusahaan

Total assets $\quad=$ Nilai total aktiva perusahaan

\section{Ukuran Perusahaan}

Jogianto (2013:254) menyebutkan ukuran perusahaan (firm size) adalah besar kecilnya perusahaan dapat diukur dengan total aktiva atau besar harta perusahaan dengan menggunakan perhitungan nilai logaritma total aktiva. Sedangkan menurut Brigham dan Houston (2010:4) ukuran perusahaan diukur dari total aktiva yang dimiliki perusahaan. Rudangga (2016) juga menyebutkan Ukuran perusahaan merupakan cerminan dari total aset yang dimiliki oleh suatu perusahaan. Berdasarkan pemaparan diatas dapat disimpulkan bahwa ukuran perusahaan merupakan suatu klasifikasi besarnya perusahaan yang dapat dilihat dari total aset perusahaan.

\section{Pengukuran Ukuran Perusahaan}

Menurut Jogiyanto (2013:282) dan Brigham dan Houston (2010:4) ukuran perusahaan dapat diukur melalui :

$$
\text { Size }=\operatorname{Ln}(\text { Total Aset })
$$

Keterangan: Size = Ukuran Perusahaan

Ln $($ Total Aset $)=$ Jumlah total aset perusahaan 
Untuk mengukur ukuran perusahaan menggunakan Logaritma Natural (Ln) dari total aktiva. Hal ini dikarenakan besarnya total aktiva masing-masing perusahaan berbeda dan bahkan mempunyai selisih yang besar, sehingga dapat menyebabkan perbedaan nilai yang ekstrim. Untuk menghindari adanya data yang tidak normal tersebut, maka data dari total aktiva perlu di Ln-kan seperti rumus yang tertera diatas.

\section{Leverage}

Menurut Sutrisno (2012:217) leverage merupakan seberapa besar dana perusahaan dibelanjai dengan utang. Kasmir (2014:112) menyatakan bahwa leverage menunjukkan sejauh mana aktiva perusahaan dibiayai dengan utang. Hery (2016:162) mendefinisikan leverage sebagai rasio solvabilitas atau rasio leverage merupakan rasio yang digunakan untuk mengukur sejauh mana aset perusahaan dibiayai dengan utang. Dengan kata lain, rasio solvabilitas atau rasio leverage merupakan rasio yang digunakan untuk mengukur seberapa besar beban utang yang harus ditanggung perusahaan dalam rangka pemenuhan aset. Berdasarkan penjelasan diatas dapat disimpulkan bahwa leverage adalah pengukuran seberapa besar aset dan dana perusahaan yang dibiayai dengan utang.

\section{Pengukuran Leverage}

Penelitian ini menggunakan jenis rasio Debt to Asset Ratio (DAR) sebagai alat pengukuran rasio leverage, karena Indiator $D A R$ mampu menggambarkan kemampuan perusahaan dalam mengelola aktivanya dan juga dapat menunjukkan seberapa besar bagian dari aktiva perusahaan tersebut yang dibiayai utang. Hal ini juga sejalan dari pengertian dari Leverage itu sendiri menurut para ahli seperti Herry (2016:162), Jogiyanto (2013:282), dan Kasmir (2012:151) yang menyatakan bahwa rasio leverage adalah rasio yang digunakan untuk mengukur sejauh mana aset perusahaan dibiayai oleh utang.

Rumus untuk mencari Debt to Asset Ratio dapat digunakan sebagai berikut :

$$
D A R=\frac{\text { Total Debt }}{\text { total asset }}
$$

Keterangan :

DAR = Debt to asset ratio

Total Debt = Jumlah total hutang perusahaan

Total assets = Jumlah total aset perusahaan

\section{Pengaruh Ukuran Perusahaan Terhadap Nilai Perusahaan}

Salah satu variabel yang menjadi pertimbangan dalam menentukan nilai perusahaan adalah ukuran perusahaan. Ukuran perusahaan merupakan cerminan dari total aset yang dimiliki oleh suatu perusahaan (Wida \& Suartana, 2014). Ukuran perusahaan yang besar memiliki kelebihan yaitu semakin mudah untuk mendapatkan pendanaan dan perhatian investor karena perusahaan yang besar lebih dikenal publik sehingga akan berpengaruh dalam peningkatan nilai perusahaan. (Rejeki \& Haryono, 2021).

Namun menurut Ibrahim (2017) ukuran perusahaan yang dilihat dari total aset perusahaan yang terlalu besar dianggap sinyal negatif bagi investor ataupun calon investor 
karena ukuran perusahaan yang terlalu besar dianggap akan menyebabkan pengawasan kegiatan operasional kurang efisien dan kurangnya efisiensi pengawasan strategi oleh jajaran manajemen, sehingga dapat mengurangi nilai perusahaan. Kondisi ini disebabkan karena adanya perbedaan kepentingan antara pemegang saham dengan manajer sehingga muncul konflik yang disebut dengan atau konflik keagenan (Jensen \& Meckling, 1976).

Pernyataan tersebut sejalan dengan penelitian Zahra (2019), yang menyatakan ukuran perusahaan berpengaruh negatif signifikan terhadap nilai perusahaan.

\section{Pengaruh Leverage Terhadap Nilai Perusahaan}

Menurut Fahmi (2014:72), rasio leverage merupakan alat untuk mengukur seberapa besar peruahaan dibiayai dengan utang. Leverage diukur menggunakan rasio DAR (Debt to Asset Ratio). Leverage merupakan gambaran dari pemakaian utang oleh perusahaan untuk membiayai kegiatan operasional perusahaan. Pengelolaan leverage sangat penting karena tingginya penggunaan leverage dapat meningkatkan nilai perusahaan yang disebabkan dari perlindungan pajak. Leverage dapat diartikan sebagai rasio yang digunakan untuk menghitung seberapa jauh dana yang disediakan kreditur, juga sebagai rasio yang membandingkan total hutang terhadap keseluruhan aktiva suatu perusahaan. Oleh sebab itu, apabila investor melihat sebuah perusahaan dengan aset yang tinggi dan rasio leverage nya juga tinggi, maka investor akan mempertimbangkan lagi untuk berinvestasi pada perusahaan tersebut. Pernyataan tersebut sejalan dengan penelitian Rudangga \& Sudiarta (2016), yang menyatakan bahwa angka leverage menunjukkan positif dan signifikan terhadap nilai perusahaan.

\section{Kerangka Konseptual}

Kerangka konseptual dapat ditunjukkan pada gambar berikut:

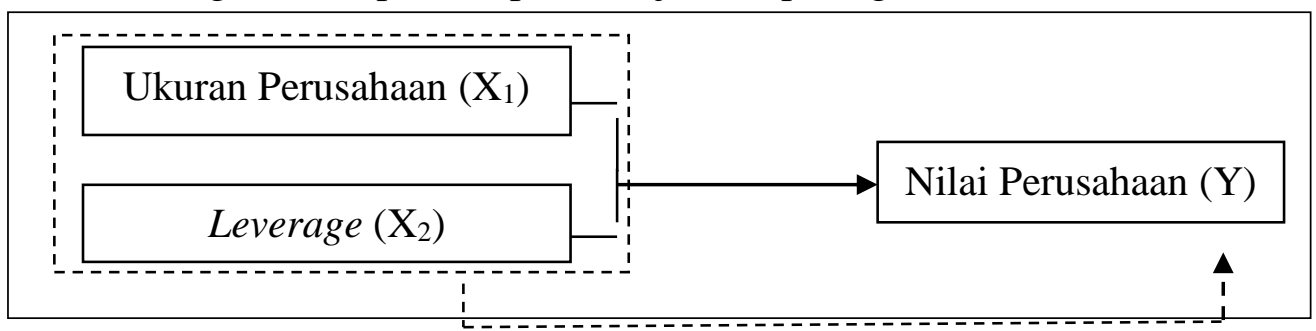

\section{Gambar 1 Kerangka Konseptual}

Hipotesis mengenai pengaruh ukuran perusahaan dan leverage terhadap nilai perusahaan pada perusahaan industry ekstil dan garmen yang terdaftar di BEI tahun 20182020 yaitu :

$\mathrm{H}_{01}=0$, Ukuran perusahaan tidak berpengaruh terhadap nilai perusahaan pada perusahaan industri tekstil dan garmen yang tedaftar di BEI tahun 2018- 2020

$\mathrm{H}_{\mathrm{a} 1} \neq 0$,Ukuran perusahaan berpengaruh terhadap nilai perusahaan pada perusahaan industri tekstil dan garmen yang tedaftar di BEI tahun 2018- 2020

$\mathrm{H}_{02}=0$, Leverage tidak berpengaruh terhadap nilai perusahaan pada perusahaan industri tekstil dan garmen yang tedaftar di BEI tahun 2018-2020. 
$\mathrm{H}_{\mathrm{a} 2} \neq 0$, Leverage berpengaruh terhadap nilai perusahaan pada perusahaan industri tekstil dan garmen yang tedaftar di BEI tahun 2018-2020.

$\mathrm{H}_{03}=0$, Ukuran perusahaan dan leverage secara simultan tidak berpengaruh terhadap nilai perusahaan pada perusahaan industri tekstil dan garmen yang terdaftar di BEI tahun 2018-2020.

$\mathrm{H}_{\mathrm{a} 3} \neq 0$, Ukuran perusahaan dan leverage secara simultan berpengaruh terhadap nilai perusahaan pada perusahaan industri tekstil dan garmen yang terdaftar di BEI tahun 2018-2020.

\section{METODE PENELITIAN}

\section{Ruang Lingkup dan Lokasi Penelitian}

Data yang digunakan dalam penelitian ini merupakan data sekunder. Data sekunder (secondary data) mengacu pada informasi yang dikumpulkan dari sumber data yang sudah ada. Artinya data diperoleh secara tidak langsung oleh penulis melalui media perantara (Sekaran 2017:130). Data sekunder yang digunakan dalam penelitian ini berupa laporan keuangan yang diambil dari website resmi pada Bursa Efek Indonesia, website Saham OK dan website resmi perusahaan bersangkutan. Sehingga peneliti tidak melakukan intervensi maupun manipulasi data.

\section{Populasi dan Sampel}

Populasi menurut Sekaran (2017:53) adalah kelompok orang, kejadian, atau hal-hal menarik di mana peneliti ingin membuat opini (berdasarkan statistik dan sampel). Populasi dalam penelitian ini yaitu seluruh laporan keuangan perusahaan aneka industri Tekstil \& Garmen yang terdaftar di Bursa Efek Indonesia periode 2018-2020 sejumlah 20 Perusahaan.

Sampel didefinisikan sebagian dari populasi. Sampel terdiri atas sejumlah anggota yang dipilih dari populasi (Sekaran 2017:54). Adapun teknik sampel yang digunakan dalam penelitian ini adalah purposive sampling. Menurut (Sugiyono 2013:122) purposive sampling adalah teknik penentuan sampel dengan pertimbangan tertentu. Penggunaan teknik purposive sampling dilakukan karena tidak semua sampel sesuai dengan kriteria yang diperlukan dalam penelitian. Berikut adalah kriteria dalam pengambilan sampel pada penelitian ini:

1. Perusahaan Industri Tekstil dan Garmen yang terdaftar di Bursa Efek Indonesia (BEI) tahun 2018-2020.

2. Perusahaan Industri Tekstil dan Garmen yang mempublikasikan secara konsisten laporan keuangan atau laporan tahunan yang telah diaudit untuk tahun 2018-2020.

Berdasarkan kriteria tersebut, dari total populasi jumlah perusahaan industri tekstil dan garmen sebanyak 20 perusahaan, diperoleh sampel sejumlah 15 perusahaan dengan periode pengamatan selama tiga tahun, dari tahun 2018-2020, sehingga jumlah sampel perusahaan yang diamati sebanyak 45 pengamatan.

\section{Metode Analisis Data}

\section{Analisis Statistik Deskriptif}

Teknik pengolahan analisis data yang digunakan dalam penelitian ini adalah statistik deskriptif. Menurut Sugiyono (2013) analisis deskriptif adalah metode statistik yang 
digunakan untuk menganalisis data dengan cara mendeskripsikan atau menggambarkan data yang telah terkumpul sebagaimana adanya, tanpa bermaksud membuat kesimpulan yang berlaku untuk umum atau generalisasi. Dalam penelitian ini menggunakan aplikasi / software SPSS versi 24.

\section{Uji Asumsi Klasik}

Uji asumsi klasik adalah persyaratan statistik yang harus dipenuhi terlebih dahulu dalam analisis regresi linear. Beberapa asumsi klasik yang digunakan yaitu uji normalitas, autokorelasi, multikolinieritas, dan heteroskedastisitas.

\section{Uji Normalitas}

Uji normalitas digunakan untuk mengkaji kenormalan variabel yang diteliti apakah data tersebut berdistribusi normal atau tidak. Hal tersebut penting karena bila data setiap variabel tidak normal, maka pengujian hipotesis tidak bisa menggunakan statistik parametik (Sugiyono, 2013: 239). Untuk melihat normalitas residual yaitu dengan menggunakan analisis grafik (plot), dilakukan dengan melihat grafik histogram yang apabila menyebar di sekitar garis diagonal dan mengikuti arah garis, maka model regresi memenuhi asumsi normalitas.

\section{Uji Multikolinearitas}

Uji multikolinearitas bertujuan untuk menguji apakah model regresi ditemukan adanya korelasi antar variabel bebas (independen). Model regresi yang baik seharusnya tidak terjadi korelasi di antara variabel independen. Jika variabel independen saling berkorelasi, maka variabel-variabel ini tidak ortogonal. Variabel ortogonal adalah variabel independen yang nilai korelasi antar sesama variabel independen sama dengan nol (Ghozali : 2013).

Untuk mengetahui ada tidaknya hubungan multikolinearitas dalam model regresi dapat dilihat dari tolerance value atau variance inflation factor (VIF).Jika nilai tolerance > 0,10 dan nilai $\mathrm{VIF}<10$, maka dapat disimpulkan bahwa tidak terjadi multikolinearitas antar variabel independen dalam model regresi.Jika nilai tolerance $<0,10$ dan nilai VIF> 10 , maka dapat disimpulkan bahwa terdapat multikolinearitas antar variabel independen dalam model regresi penelitian tersebut (Sekaran, 2017).

\section{Uji Heteroskedastisitas}

Menurut Sunyoto (2013) uji heteroskedastisitas adalah keadaan dimana dalam model regresi terjadi ketidaksamaan varian dari residual pada suatu pengamatan ke pengamatan yang lain. Model regresi yang baik adalah tidak terjadi heterokedastisitas. Pengujian heteroskedastisitas menggunakan grafik scatterplot dilakukan dengan cara melihat grafik scatterplot antara standarzided value (ZPRED) dengan stundentized residual (SRESID), ada tidaknya pola tertentu pada grafik scatterplot antara SRESID dan ZPRED dimana sumbu Y adalah Y yang telah diprediksi dan sumbu X adalah residual (Y prediksi - Y sesungguhnya).

\section{Uji Autokorelasi}

Menurut Ghozali (2013) uji autokorelasi bertujuan untuk menguji apakah dalam model regresi linear ada korelasi antara kesalahan pengganggu pada periode $t$ dengan kesalahan pengganggu. Autokorelasi merupakan korelasi antara anggota observasi yang disusun menurut waktu atau tempat. Model regresi yang baik seharusnya tidak terjadi autokorelasi. Metode pengujian ini menggunakan uji durbin-watson (dw test). 
Jika nilai Durbin watson terletak diantara -2 sampai +2 dapat disimpulkan bahwa model regresi bebas dari autokorelasi, sedangkan jika nilai durbin-watson terletak dibawah 2 berarti terdapat autokorelasi positif dan jika nilai durbin-watson terletak diatas +2 dapat disimpulkan bahwa terjadi autokorelasi negatif (Santoso, 2012:241).

\section{Metode Analisis Data}

Metode analisis yang digunakan dalam penelitian ini adalah analisis regresi linear berganda. Menurut sugiyono (2013:277) analisis regresi linier beganda bermaksud meramalkan bagaimana keadaan (naik turunnya) variabel dependen, bila dua atau lebih variabel independen sebagai faktor prediktor dimanipulasi (dinaik turunkan nilainya). Jadi analisis regresi berganda akan dilakukan bila jumlah variabel independennya minimal 2 .

Persamaan regresi linier berganda yang ditetapkan adalah sebagai berikut:

Keterangan:

$$
Y=\alpha+b_{1} x_{1}+b_{2} x_{2}+\varepsilon
$$

$$
\begin{aligned}
& \mathrm{Y}=\text { Nilai Perusahaan } \\
& \alpha \quad=\text { Koefisien Konstanta } \\
& b_{1} b_{2}=\text { Koefisien regresi } \\
& X_{1} \quad=\text { Ukuran Perusahaan } \\
& X_{2} \quad=\text { Leverage } \\
& \text { e } \quad=\text { Error, variabel gangguan }
\end{aligned}
$$

\section{HASIL DAN PEMBAHASAN}

Pada penelitian ini yang menjadi objek penelitian adalah perusahaan industri tekstil dan garmen yang terdaftar di BEI. Data yang digunakan adalah laporan keuangan tahunan 2018-2020 pada perusahaan industri tekstil dan garmen. Penelitian ini merupakan penelitian kuantitatif dengan menggunakan data sekunder yaitu data laporan keuangan perusahaan. Berdasarkan kriteria pemilihan sampel maka didapatkan bahwa penelitian memiliki 45 observasi. Analisis data dilakukan dengan menggunakan metode regresi linier berganda

\begin{tabular}{|c|c|c|c|c|c|}
\hline \multicolumn{6}{|c|}{ Descriptive Statistics } \\
\hline & $\mathrm{N}$ & Minimum & Maximum & Mean & Std. Deviation \\
\hline Tobin's Q & 45 &, 39 & 5,21 & 1,3687 & 1,13471 \\
\hline Size & 45 & 17,35 & 21,34 & 18,8613 & 1,14889 \\
\hline Leverage & 45 &, 08 & 5,17 & 9262 & 1,18465 \\
\hline Valid N (listwise) & 45 & & & & \\
\hline
\end{tabular}
dengan bantuan program SPSS versi 24 .

\section{Deskripsi data penelitian}

Pada penelitian ini dilakukan pengujian pengaruh ukuran perusahaan dan leverage sebagai variabel independen terhadap nilai perusahaan sebagai variabel dependen. Deskripsi dari masing-masing variabel dijabarkan sebagai berikut:

\section{Tabel 1 . Deskriptif Statistik}

Sumber: Data Olahan Penulis (2021) 
Berdasarkan hasil pengujian pada Tabel 1 di atas, diketahui bahwa $\mathrm{n}$ atau jumlah data yang digunakan sebanyak 45 sampel yang diperoleh dari data 15 perusahaan dikalikan dengan periode penelitian yaitu tiga tahun. Variabel nilai perusahaan menunjukkan nilai minimum sebesar 0,39 terdapat pada perusahaan PT. Polychem Indonesia Tbk di tahun 2019 sedangkan nilai tertingginya sebesar 5,21 pada perusahaan PT. Asia Pasific Fibers Tbk ditahun 2020 dengan mean sebesar 1,37 dan nilai standar deviation sebesar 1,113 lebih kecil dari nilai rata-rata yang menunjukkan data terdistribusi baik karena tingkat penyimpangan lebih kecil dari rata-rata.Variabel ukuran perusahaan yang diproksikan oleh size menunjukkan nilai minimum sebesar 17,35 pada perusahaan Sunson Textile Manufacturer Tbk di tahun 2020 dan ukuran perusahaan terbesar sebesar 21,34 pada perusahaan PT. Sri Rejeki Isman di tahun 2020, dengan nilai mean 18,86 dan standar deviation sebesar 1,114 lebih kecil dari nilai rata-rata yang menunjukkan data terdistribusi baik karena tingkat penyimpangan lebih kecil dari rata-rata. Variabel leverage minimum didapatkan pada perusahaan PT. Tifico Fiber Indonesia di tahun 2019 sebesar 0,08 dan nilai maksimum sebesar 5,17 pada perusahaan PT. Asia Pasific Fibers Tbk di tahun 2020. Nilai rata-rata variabel leverage beberada di 0,92 dan standar deviation sebesar 1,184 menunjukkan bahwa data yang digunakan bervariasi.

\section{Uji Asumsi Klasik}

\section{Uji Normalitas}

Hasil uji normalitas dengan menggunakan menggunakan Normal probability plot, dapat dilihat pada Gambar 2 berikut ini:

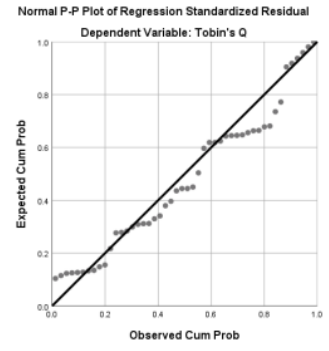

\section{Gambar 2 P-Plot Normalitas}

Sumber: Data Olahan SPSS 2021

Berdasarkan gambar 2 menunjukkan bahwa data menyebar di sekitar garis diagonal dan mengikuti arah garis diagonal. Oleh karena itu data berdistribusi normal.

\section{Uji Multikolinearitas}

Uji multikolinearitas digunakan untuk mengetahui apakah dalam model regresi ditemukan adanya korelasi antara variabel inpenden. Untuk mendeteksi ada atau tidaknya multikolinearitas dalam suatu model regresi dapat diketahui dari nilai tolerance dan variance inflation faktor $(V I F)$.Jika nilai tolerance $>0,10$ dan nilai $V I F<10$, maka tidak terjadi multikolinearitas antar variabel independen dalam model regresi. Jika nilai tolerance $<0,10$ dan nilai $V I F>10$, maka terdapat multikolinearitas antar variabel independen dalam model regresi penelitian tersebut (Sekaran, 2017). Hasil pengujian multikolinearitas dapat dilihat sebagai berikut: 


\section{Tabel 2. Pengujian Multikolinearitas}

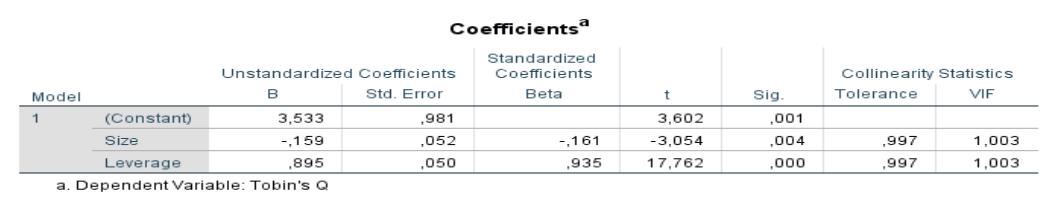

Sumber : Data Olahan SPSS (2021)

Berdasarkan tabel 1, diketahui bahwa nilai tolerance pada variabel Ukuran Perusahaan dan Leverage adalah 0,997 lebih besar dari 0,10 dan nilai VIF pada variabel Ukuran Perusahaan dan Leverage adalah 1,003 kurang dari 10, maka dapat disimpulkan pada model regresi yang terbentuk tidak terjadi gejala multikolinearitas.

\section{Uji Heteroskedastisitas}

Uji heteroskedastisitas bertujuan untuk menguji apakah dalam model regresi terjadi ketidaksamaan varians residual dari satu pengamatan ke pengamatan lain (Ghozali, 2013). Dasar analisis heteroskedastisitas adalah jika ada pola tertentu, seperti titik-titik yang membentuk pola tertentu yang teratur, maka terjadi heteroskedastisitas. Jika pola yang terbentuk tidak jelas atau titik-titik menyebar di atas dan dibawah angka nol (0) pada sumbu Y, maka tidak terjadi heteroskedastisitas. Hasil Uji Heteroskedastisitas dapat dilihat pada Gambar 3 sebagai berikut:

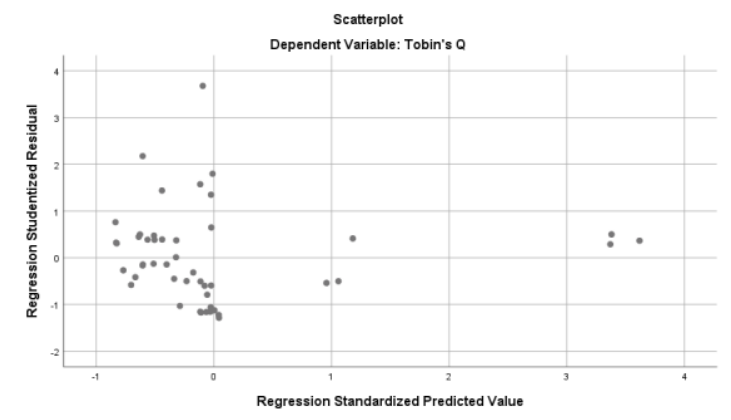

\section{Gambar 3 Diagram Pencar (Scatterplot)}

Sumber: Hasil Pengolahan Data SPSS, 2021

Pada gambar 3 dapat dilihat bahwa plot menyebar tanpa membentuk pola tertentu dan data menyebar di atas dan bawah angka 0 pada sumbu Y. sehingga dapat disimpulkan bahwa tidak terdapat heteroskedastisitas pada model regresi.

\section{Uji Autokorelasi}

Uji autokorelasi bertujuan untuk menguji apakah dalam model regresi linier ada korelasi antara kesalahan pengganggu pada periode $t$ dengan kesalahan pengganggu pada periode t-1 atau periode sebelumnya. Dalam penelitian ini di uji dengan Durbin-watson untuk mengetahui ada tidaknya autokorelasi. Adapun hasil dari pengujian autokorelasi dapat dilihat pada tabel berikut: 


\section{Tabel 3. Uji Autokorelasi}

Model Summary

\begin{tabular}{ll|r|r|r|r} 
Model & R & R Square & \multicolumn{1}{|c}{$\begin{array}{c}\text { Adjusted R } \\
\text { Square }\end{array}$} & $\begin{array}{c}\text { Std. Error of } \\
\text { the Estimate }\end{array}$ & \multicolumn{1}{c}{$\begin{array}{c}\text { Durbin- } \\
\text { Watson }\end{array}$} \\
\hline 1 &, $940^{a}$ &, 884 &, 878 &, 39557 &, 996 \\
\hline
\end{tabular}

a. Predictors: (Constant), Leverage, Size

b. Dependent Variable: Tobin's $Q$

Sumber: Data Olahan Penulis (2021)

Berdasarkan hasil uji autokorelasi pada tabel 4, nilai Durbin-watson adalah 0,996. Karena nilai Durbin-watson terletak diantara -2 sampai +2 , maka dapat disimpulkan bahwa tidak ada autokorelasi dan model regresi tersebut dapat digunakan untuk mengambil keputusan.

\section{Hasil Pengujian Hipotesis}

\section{Analis Regresi Linear Berganda}

Analsis regresi linear berganda digunakan untuk mengetahui arah hubungan antara variabel independen, yaitu Ukuran perusahaan (Ln Total Asset) dan Leverage (DAR) dengan variabel dependen Nilai Perusahaan (Tobin's Q). Hasil pengujian regresi linear berganda dapat dilihat pada tabel 3 berikut:

\section{Tabel 4. Analisis Regresi Linier Berganda}

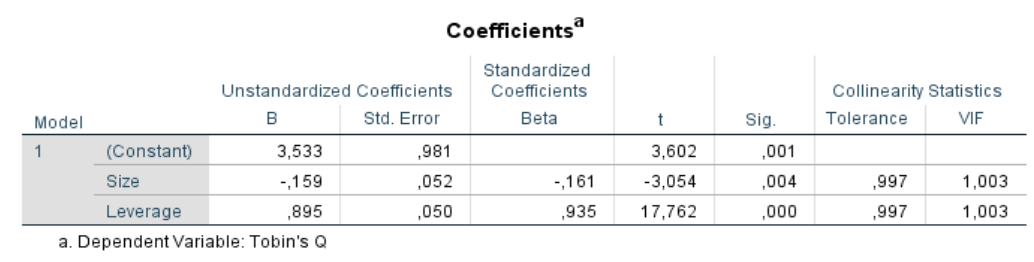

Sumber: Data Diolah (2021)

Berdasarkan Tabel 3, maka dapat dirumuskan persamaan regresi linier berganda untuk penelitian ini adalah sebagai berikut:

$$
Y=\alpha+b_{1} x_{1}+b_{2} x_{2}+\varepsilon
$$

\section{Nilai Perusahaan $=3,533-0,159$ Size $+0,895$ Leverage}

Dari persamaan regresi diatas dapat diketahui bahwa:

1. Konstanta bernilai 3,533 menunjukkan bahwa jika variabel independen dianggap konstan, maka rata-rata nilai perusahaan sebesar 3,533

2. Koefesien Ukuran Perusahaan (Size) bernilai -0,159 menunjukkan bahwa setiap penurunan 1 satuan size maka akan meningkatkan nilai perusahaan sebesar 0,159 atau setiap kenaikan 1 satuan size maka akan menurunkan nilai perusahaan sebesar 0,159 dengan asumsi variabel lain konstan.

3. Koefesien Leverage 0,895 menyatakan bahwa setiap penambahan 1 satuan leverage maka akan meningkatkan nilai perusahaan sebesar 0,895 . 


\section{Hasil Pengujian Hipotesis Secara Parsial}

Hasil uji t digunakan untuk mengetahui signifikansi pengaruh masing-masing variabel independen ukuran perusahaan dan leverage terhadap variabel dependen nilai perusahaan secara parsial. Hasil dari pengujian hipotesis yang menggunakan SPSS versi 24, diperoleh hasil uji hipotesis yang merupakan uji hubungan kausalitas dari masing-masing variabel penelitian sebagaimana disajikan pada tabel 4 berikut ini :

\section{Tabel 5. Uji t}

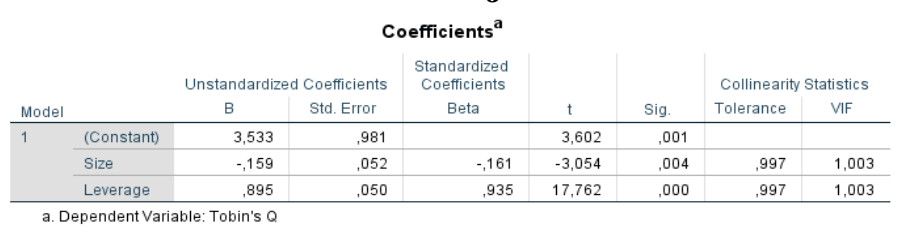

Sumber: Data olahan SPSS (2021)

Diketahui $\mathrm{t}$ tabel dengan $\mathrm{a}=0,05, \mathrm{n}=45$ dan $\mathrm{k}=2$ serta $\mathrm{df}(\mathrm{n}-\mathrm{k}-1)=45-2-1=42$. Dapat dilihat $\mathrm{t}$ tabel yatu $=1,682$ maka dapat hasil pengujian masing-masing variabel independen secara parsial sebagai berikut:

\section{Pengaruh Ukuran Perusahaan Terhadap Nilai Perusahaan}

Berdasarkan hasil uji hipotesis secara parsial pada Tabel 6 diketahui thitung sebesar 3,054 dan $t_{\text {tabel }}$ sebesar 1,682 sehingga nilai $t_{\text {hitung }}>t_{\text {tabel }}(3,054>1,679)$ dengan arah koefisien $\beta$ negatif. Tabel diatas juga menunjukkan nilai signifikansi t sebesar $0,004<0,05$. sehingga hasil pengolahan data menunjukkan $\mathrm{H}_{\mathrm{a} 1} \neq 0$ atau hipotesis alternatif 1 diterima atau $\mathrm{H}_{01}=0$ ditolak, dapat disimpulkan variabel ukuran perusahaan berpengaruh negatif signifikan secara parsial terhadap nilai perusahaan.

\section{Pengaruh Leverage Terhadap Nilai Perusahaan}

Berdasarkan hasil uji hipotesis secara parsial pada tabel 4.6 diketahui $\mathrm{T}_{\text {hitung }}$ sebesar 17,762 dan $\mathrm{T}_{\text {tabel }}$ sebesar 1,682 sehingga $\mathrm{T}_{\text {hitung }}>\mathrm{T}_{\text {tabel }}(17,762>1,682)$ dengan arah koefisien $\beta$ positif. Tabel diatas juga menunjukkan nilai signifikansi t sebesar $0,00<0,05$. Sehingga hasil pengolahan data menunjukkan $\mathrm{H}_{\mathrm{a} 2} \neq 0$ diterima atau hipotesis alternatif 2 diterima atau $\mathrm{H}_{02}=0$ ditolak, yang berarti variabel leverage secara parsial berpengaruh positif dan signifikan terhadap nilai perusahaan.

\section{Hasil Pengujian Hipotesis Secara Simultan}

Uji F dilakukan untuk mengetahui apakah semua variabel bebas (secara simultan) mempunyai pengaruh yang signifikan terhadap variabel terikat (Sunyoto, 2013:54). Hasil pengujian hipotesis secara simultan dapat dilihat pada tabel 5 :

\begin{tabular}{|c|c|c|c|c|c|c|}
\hline & \multicolumn{6}{|c|}{ Tabel 6. Uji F (ANOVA) } \\
\hline Model & & $\begin{array}{l}\text { Sum of } \\
\text { Squares }\end{array}$ & df & Mean Square & $\mathrm{F}$ & Sig. \\
\hline \multirow[t]{3}{*}{1} & Regression & 50,081 & 2 & 25,041 & 160,025 &, $000^{\mathrm{b}}$ \\
\hline & Residual & 6,572 & 42 & 156 & & \\
\hline & Total & 56,653 & 44 & & & \\
\hline
\end{tabular}

Sumber: Data Diolah (2021) 
Berdasarkan hasil pengujian pada Tabel 5 diatas, diperoleh bahwa nilai $F_{\text {hitung }}$ $160,025>F_{\text {tabel }} 3,22$ dengan signifikansi $0,00<0,05$ maka dapat disimpulkan secara simultan variabel ukuran perusahaan dan leverage berpengaruh signifikan terhadap variabel dependen yaitu nilai perusahaan.

\section{Koefisien Determinasi $\left(\mathbf{R}^{\mathbf{2}}\right)$}

Koefisien Determinasi $\left(\mathrm{R}^{2}\right)$ dilakukan untuk mengukur sejauh mana kemampuan variabel independen dalam menjelaskan variabel dependen. Nilai koefisien determinasi menyatakan proporsi keragaman pada setiap variabel bergantung yang mampu dijelaskan oleh praduganya. Hasil Uji Koefisien Determinasi dapat dilihat pada tabel 6.

Tabel 7. Koefisien Determinasi $\left(\mathbf{R}^{2}\right)$

\begin{tabular}{|c|c|c|c|c|c|}
\hline \multicolumn{6}{|c|}{ Model Summary } \\
\hline Model & $\mathrm{R}$ & R Square & $\begin{array}{c}\text { Adjusted R } \\
\text { Square }\end{array}$ & $\begin{array}{l}\text { Std. Error of } \\
\text { the Estimate }\end{array}$ & $\begin{array}{l}\text { Durbin- } \\
\text { Watson }\end{array}$ \\
\hline 1 & $940^{a}$ & 884 & 878 & 39557 &, 996 \\
\hline
\end{tabular}

Sumber: Data Diolah (2021)

Berdasarkan Tabel 7 diketahui bahwa nilai Koefesien Determinasi didapatkan nilai sebesar $0,884 \times 100 \%=88,4 \%$ artinya bahwa variabel ukuran perusahaan dan leverage secara simultan berpengaruh terhadap variabel nilai perusahaan, sedangkan sisanya $11,6 \%$ dipengaruhi oleh variabel yang tidak termasuk dalam penelitian ini.

\section{Pembahasan Hasil Penelitian}

\section{Pengaruh Ukuran Perusahaan Terhadap Nilai Perusahaan Industri Tekstil dan} Garmen yang Terdaftar di Bursa Efek Indonesia Periode 2018-2020

Berdasakan hasil pengujian hipotesis menunjukkan bahwa ukuran perusahaan berpengaruh negatif signifikan terhadap nilai perusahaan. Hal ini dapat dilihat dari nilai thitung $>t_{\text {tabel }}(3,054>1,679)$ dengan arah koefisien $\beta$ negatif dan besar koefisien regresi $-0,159$. sehingga hasil pengolahan data menunjukkan $\mathrm{H}_{\mathrm{a} 1} \neq 0$ diterima dan $\mathrm{H}_{0}=0$ ditolak atau hipotesis yang menyatakan bahwa ukuran perusahaan berpengaruh signifikan terhadap nilai perusahaan diterima. Hasil pengujian memperoleh nilai signifikansi $0,001<\alpha=0,05$ menunjukkan bahwa Ha diterima dan signifikan terhadap nilai perusahaan industri tekstil dan garmen yang terdaftar di Bursa Efek Indonesia.

Pengaruh negatif tersebut disebabkan karena pada industri tekstil dan garmen yang terdaftar di Bursa Efek Indonesia tahun 2018-2020 memiliki aset yang besar seperti pabrik dan mesin, namun aset tersebut tidak digunakan secara produktif, hal tersebut dapat dilihat dari jumlah aset tetap perusahaan yang besar. Kemampuan perusahaan dalam mengelola aset tetap yang ada belum memberikan keyakinan bagi investor untuk berinvestasi pada perusahaan tersebut. Hal ini dapat dilihat dari harga saham perusahaan industri tekstil dan 
garmen yang tidak meningkat sehingga memberikan pengaruh turunnya nilai perusahaan pada sebagian besar industri tekstil dan garmen yang terdaftar di Bursa Efek Indonesia.

Oleh karena itu dapat disimpulkan bahwa ukuran perusahaan memiliki pengaruh negatif signifikan terhadap nilai perusahaan. Hasil ini mendukung penelitian yang dilakukan oleh Astriani (2014) dan Rumondor, Mangantar, \& Sumaran (2015) dan Rahmawati (2015), yang menyatakan bahwa ukuran perusahaan berpengaruh negatif dan signifikan terhadap nilai perusahaan. Tetapi bertolak belakang dengan penelitian yang dilakukan oleh Suryandani (2018) dan Sholekah (2014) yang menyatakan bahwa ukuran perusahaan tidak berpengaruh terhadap nilai perusahaan.

\section{Pengaruh Leverage Terhadap Nilai Perusahaan Industri Tekstil dan Garmen yang Terdaftar di Bursa Efek Indonesia Periode 2018-2020}

Berdasarkan hasil pengujian hipotesis dapat dilihat bahwa leverage berpengaruh positif dan signifikan terhadap nilai perusahaan.. Hal ini dapat dilihat dari nilai $t_{\text {hitung }}>t_{\text {tabel }}$ $(17,762>1,682)$ dengan arah koefisien $\beta$ positif dan besar koefisien regresi 0,895 . sehingga hasil pengolahan data menunjukkan $\mathrm{H}_{\mathrm{a} 2} \neq 0$ diterima dan $\mathrm{H}_{02}=0$ ditolak atau hipotesis yang menyatakan bahwa leverage berpengaruh signifikan terhadap nilai perusahaan diterima. Hasil pengujian memperoleh nilai signifikansi $0,001<\alpha=0,05$ menunjukkan bahwa Ha diterima dan signifikan terhadap nilai perusahaan industri tekstil dan garmen yang terdaftar di Bursa Efek Indonesia.

Pengaruh positif tersebut memiliki arti bahwa semakin tinggi leverage maka semakin tinggi pula nilai perusahaan yang diperoleh. Hal ini menunjukkan bahwa perusahaan mampu dalam mengelola hutangnya dan mengupayakan kinerja terbaiknya sehingga menciptakan nilai perusahaan yang baik pula. Rasio ini juga dapat memberikan kesempatan bagi perusahaan untuk berekspensi sehingga dapat meningkatkan keuntungan yang dihasilkan dan pada akhirnya dapat memberikan pengaruh positif terhadap nilai perusahaan.

Hasil penelitian ini sejalan dengan penelitian yang dilakukan oleh Rudangga (2016), Prasetyorini (2013) dan Setiana \& Rahyu (2012) yang menyatakan bahwa leverage berpengaruh positif \& signifikan terhadap nilai perusahaan. Tetapi berbanding terbalik dengan penelitian Al-Slehat (2020) dan Astriani (2014) yang menyatakan bahwa leverage tidak berpengaruh terhadap nilai perusahaan.

\section{Pengaruh Ukuran Perusahaan dan Leverage Terhadap Nilai Perusahaan Industri Tekstil dan Garmen yang Terdaftar di Bursa Efek Indonesia Periode 2018-2020}

Hasil pengujian hipotesis secara simultan dalam penelitian ini nilai Ftabel dengan tiga variabel penelitian dan jumlah $\mathrm{n}=45$ dan nilai Ftabel yaitu sebesar 3,22. Berdasarkan hasil pengujian diperoleh nilai $F_{\text {hitung }} 160,025>\mathrm{F}_{\text {tabel }} 3,22$ dengan nilai signifikansi $0,00<$ 0,05. Sehingga hasil pengujian menunjukkan $\mathrm{H}_{\mathrm{a} 3} \neq 0$ diterima, atau $\mathrm{H}_{03}=0$ ditolak, maka dapat disimpulkan bahwa secara simultan ukuran perusahaan dan leverage berpengaruh signifikan terhadap nilai perusahaan dengan besar pengaruh atau koefisien determinasi 88,9\%. Hasil penelitian ini sesuai dengan penelitian yang dilakukan oleh Astriani (2014), dan Rudangga \& Sudiarta (2016), yang menyatakan bahwa ukuran perusahaan dan leverage berpengaruh signifikan terhadap nilai perusahaan. 


\section{KESIMPULAN, KETERBATASAN DAN SARAN}

Berdasarkan hasil analisis data dan pembahasan tentang pengaruh ukuran perusahaan dan leverage terhadap nilai perusahaan pada perusahaan industri tekstil dan garmen yang terdaftar di Bursa Efek Indonesia periode 2018-2020, dapat disimpulkan bahwa Ukuran Perusahaan secara parsial berpengaruh terhadap nilai perusahaan industri tekstil dan garmen yang terdaftar di Bursa Efek Indonesia periode 2018-2020, Leverage secara parsial berpengaruh terhadap nilai perusahaan pada perusahaan industri tekstil dan garmen yang terdaftar di Bursa Efek Indonesia periode 2018-2020. Ukuran perusahaan dan leverage secara simultan berpengaruh terhadap nilai perusahaan pada perusahaan industri tekstil dan garmen yang terdaftar di Bursa Efek Indonesia periode 2018-2020. Keterbatasan Penelitian ini hanya dilakukan pada perusahaan garmen dan hanya mengambil beberapa rasio. Berdasarkan hasil penelitian dan kesimpulan diatas, maka saran-saran yang dapat diberikan berkaitan dengan perkembangan pasar modal di indonesia adalah sebagai berikut :Bagi perusahaan, terutama manajemen perlu meningkatkan kinerjanya dalam mengelola kebijakan hutangnya agar dapat memberikan kontribusi terhadap peningkatan nilai perusahaan dimasa mendatang. Manajemen juga perlu meningkatkan produktifitas aktivanya sebagai indikator ukuran perusahaan (size) agar dapat memberikan kontribusi terhadap peningkatan nilai perusahaan. Bagi Investor sebaiknya memperhatikan rasio leverage dan ukuran perusahaan sebelum memutuskan untuk menginvestasikan sahamnya pada suatu perusahaan, karena dari penelitian ini rasio leverage dan ukuran perusahaan berpengaruh terhadap nilai perusahaan. Selanjutnya investor juga perlu memerhatikan faktor lain seperti earning per share, likuiditas dan faktor fundamental lainnya untuk melihat kelayakan investasi saham pada suatu perusahaan. Bagi peneliti selanjutnya, agar dapat menambah variabel lain yang dapat mempengaruhi nilai perusahaan baik dari faktor fundamental lain seperti kepemilikan manajerial, kebijakan dividen, dan lainnya yang mempengaruhi nilai perusahaan. Penelitian selanjutnya juga diharapkan dapat menambahkan sampel perusahaan dan periode waktu yang lebih banyak agar hasil penelitian lebih akurat.

\section{DAFTAR PUSTAKA}

AyuningTyas, D. (2019, Oktober 3). CNBC Indonesia. Dipetik April 15, 2021, dari Duh! Emiten Tekstil Terpukul dan Harga Saham Anjlok: https://www.cnbcindonesia.com

Bagaskara, R. S., Titisari, K. H., \& Dewi, R. R. (2021). Pengaruh Profitabilitas, leverage, ukuran perusahaan dan kepemilikan manajerial terhadap nilai perusahaan. Forum Ekonomi, 23 (1) , 29-38.

Brealey, Myers, \& Marcus. (2007). Dasar-Dasar Manajemen Keuangan. Jakarta: Erlangga.

Brigham, F. E., \& Houston, J. F. (2010). Dasar-Dasar Manajemen Keuangan Edisi 11. Jakarta: Salemba Empat.

Chairunnisa, R. (2019). Likuiditas, Aktivitas, dan Pofitabilitas Terhadap Nilai Perusahaan Automotive yang Terdaftar di BEI. Jurnal Ekonomi Manajemen \& Bisnis Vol.20, No.2 , 146-160.

Chung, K. H., \& Pruitt, S. W. ((Autumn 1994)). A Simple Approximation of Tobin's Q. Financial Manajemen Vol.23, No.3, Venture Capital Special Issue , 70-74.

Fahmi, I. (2014). Analisa Kinerja Keuangan. Bandung: Alfabeta. 
Firdaus, M. F. (2019). Pengaruh Profitabilitas, Leverage, dan ukuran perusahaan terhadap nilai perusahaan. E-Proceeding of Management : Vol.6 , 5793-5799.

Ghozali, I. (2016). Analisis Multivariete Dengan Program IBM SPSS 23 (Edisi 8). Cetakan ke VIII. Semarang: Badan Penerbit Universitas Diponegoro.

Ghozali, I. (2013). Aplikasi Analisis Multivariate dengan Program IBM SPSS 21 Update PLS Regresi. Semarang: Badan Penerbit Universitas Diponegoro.

Harmono. (2014). Manajemen Keuangan Berbasis Balanced Scorecard, Pendekatan Teori, Kasus, dan Riset Bisnis. Jakarta: Bumi Aksara.

Hery. (2015). Analisis Kinerja Manajemen. Jakarta: Grasindo.

Horne, J. C., \& Wachowicz, J. M. (2012). Prinsip-Prinsip Manajemen Keuangan (Edisi 13). Jakarta: Salemba Empat.

Husnan. (2012). Dasar-Dasar Manajemen Keuangan. Yogyakarta: UPP STIM YKPN.

I Gusti Ngurah Gede Rudangga, G. M. (2016). Pengaruh Ukuran Perusahaan, Leverage, dan Profitabilitas Terhadap Nilai Perusahaan. E-Jurnal Manajemen Unud Voli.5, No.7 , 4394-4422.

Jogianto, H. (2013). Teori Portofolio dan Analisis Investasi. Yogyakarta: BPFE.

Johnson, M. C., \& Meckling, W. H. (1976). Theory of the firm: Managerial behavior, agency costs and ownership structure. Journal of Financial Economics, Volume 3, Issue 4 , 305-360.

Kasmir. (2014). Analisis Laporan Keuangan. Jakarta: PT. Rajagrafindo Persada.

Lin, F. L., \& Chang, T. (2010). Does Family Ownership Affect Firm Value in Taiwan? A Panel Thershold Regression Analysis. International Research Journal of Finance and Economics, 42 , 45-53.

M, I. (2017). Capital Structure and Firm Value in Nigerian Listed Manufacturing Companies: an Empirical Investigation using Tobin's Q Model. International Journal of Innovative Research in Social Science \& Strategic Management Techniques, 4(2), 112-125.

Pratama, \& Wiksuana. (2016). Pengaruh Ukuran Perusahaandan Leverage Terhadap Nilai Perusahaan Dengan Profitabilitas Sebagai Variabel Mediasi. E-Jurnal Manajemen Universitas Udayana .

Rahayu, M., \& Sari, B. (2018). Faktor-faktor yang mempegaruhi nilai perusahaan. IKRAITH HUMANIORA : Jurnal Sosial dan Humaniora Vol 2 Nomor 1 , 69-76.

Rahmawati, A., Nurdin, D., \& K.Bidin, C. R. (2015). Pengaruh Kepemilikan Manajerial dan Ukuran Perusahaan Terhadap Nilai Perusahaan. Jurnal Ilmu Manajemen Universitas Tadulako Vol.1 , No. 1, 001-006.

Ramhonah, Z., Solikin, I., \& Sari, M. (2019). Pengaruh Struktur Modal, Ukuran Perusahaan, Pertumbuhan Perusahaan, dan Profitabilitas Terhadap Nilai Perusahaan. Jurnal Riset Akuntansi dan Keuangan, 7 (1), 67-82.

Rejeki, H. T., \& Haryono, S. (2021). Pengaruh Leverage dan Ukuran Perusahaan Terhadap Nilai Perusahaan di Indonesia. Invoice: Jurnal Ilmu Akuntansi Vol.3, nomor 1, 1-9.

Riyanto, B. (2011). Dasar-Dasar Pembelajaran Perusahaan. Yogyakarta: BPFE. 
Rudangga, I. G., \& Sudiarta, G. M. (2016). Pengaruh Ukuran Perusahaan, Leverage, dan Profitabilitas Terhadap Nilai Perusahaan. E-Jurnal Manajemen Unud Voli.5, No.7, 4394-4422.

Santoso, S. (2012). Panduan Lengkap SPSS Versi 20. Jakarta: PT. Elex Media Komputindo.

Sartono, A. (2010). Manajemen Keuangan Teori dan Aplikasi, Edisi empat. Yogyakarta: BPFE.

Sekaran, U. (2017). Metode Penelitian Untuk Bisnis. Jakarta: Salemba Empat.

Sjahrial, D. (2009). Manajemen Keuangan. Jakarta: Mitra Wacana Media.

Smithers, A., \& Wright, S. (2007). Valuing Wall Street : Protecting Wealth in Turbulent Markets. McGraw Hill.

Sudana, I. M. (2011). Manajemen Keuangan Perusahaan. Jakarta: Erlangga.

Sudarma, I. K., \& Darmayanti, N. P. (2017). Pengaruh Csr, Kepemilikan Manajerial Dan Profitabilitas Terhadap Nilai Perusahaan Sektor Pertambangan Pada Indeks Kompas 100. E-Jurnal Manajemen, 6(4) , 1906 - 1932.

Sugiyono. (2017). Metode Penelitian Kuantitatif, Kualitatif, dan R\&D. Bandung: CV Alfabeta.

Sujarweni, \& Wiratama. (2015). Metodologi Penelitian Bisnis dan Ekonomi. Yogyakarta: Pustaka Baru Press.

Sunyoto, D. (2013). Metodologi Penelitian Akuntansi. Bandung : Refika Adimata.

Sutrisno. (2012). Manajemen Keuangan Teori, Konsep dan Aplikasi. Yogyakarta: Ekonisa.

Tobing, S. (2020, April 28). Katadata.co.id. Dipetik April 21, 2021, dari Industri Tekstil RI saat Pandemi: Sudah Jatuh, Tertimpa Tangga: https://katadata.co.id

Wida, N. P., \& Suartana, I. W. (2014). ISSN: 2302-8556 E-Jurnal Akuntansi Universitas Udayana 9.3 , 575-590. 